\title{
Native American Ceramic Assemblages from Sites in Tyler County, in Southeast Texas
}

Timothy K. Perttula

Heritage Research Center, Stephen F. Austin State University

Follow this and additional works at: https://scholarworks.sfasu.edu/ita

Part of the American Material Culture Commons, Archaeological Anthropology Commons, Environmental Studies Commons, Other American Studies Commons, Other Arts and Humanities Commons, Other History of Art, Architecture, and Archaeology Commons, and the United States History Commons

Tell us how this article helped you.

This Article is brought to you for free and open access by the Center for Regional Heritage Research at SFA ScholarWorks. It has been accepted for inclusion in Index of Texas Archaeology: Open Access Gray Literature from the Lone Star State by an authorized editor of SFA ScholarWorks. For more information, please contact cdsscholarworks@sfasu.edu. 
Native American Ceramic Assemblages from Sites in Tyler County, in Southeast Texas

\section{Creative Commons License}

\section{(c) (1) (8)}

This work is licensed under a Creative Commons Attribution-NonCommercial 4.0 International License 


\title{
Native American Ceramic Assemblages from Sites in Tyler County, in Southeast Texas
}

\author{
Timothy K. Perttula
}

\section{Introduction}

As part of a WPA-funded project, Gus E. Arnold of the University of Texas carried out archaeological survey investigations in Tyler County, Texas, between October 1939 and August 1940. During that time he recorded three sites in the Neches River basin with Native American ceramic vessel sherd assemblages, in an area just south of the known southern boundary of the Southern Caddo Area in East Texas (cf. Perttula 2012:Figure 1-2). These ceramic assemblages, curated at the Texas Archeological Research Laboratory at The University of Texas at Austin (TARL), are the subject of this article.

\section{Sites}

41TL7, Peachtree Village (41TL10), and the Sturrock Place (41TL13) are in the upper part of Southeast Texas in the Neches River basin (Figure 1), about 20-30 km south of Lake Sam Rayburn on the Angelina River, and just south of the Caddo area in East Texas as it is presently recognized. They are in the Pineywoods physiographic province (see Diggs et al. 2006). 41 TL 7 and the Sturrock Place, habitation sites, are on Billiams Creek (sometimes spelled Billums), a northward-flowing tributary to the Neches River. The Sturrock Place site covered an estimated $45 \times 30$ m area on a sandy ridge overlooking Billiams Creek; Arnold mentioned that the site might also have Native American burials, but provided no details.

The Peachtree Village site was described by Arnold as about 1 acre in size in a bottomland setting situated adjacent to a spring and spring branch, and 0.5 miles west of the Kirby family home in Chester, Texas. As part of the proposed Rockland Reservoir on the Neches River, Dr. Edward Jelks visited the site in June 1954, and collected three ceramic sherds (one plain and two incised sherds) from the surface.

\section{$41 T L 7$}

There are 256 ceramic sherds from grog-, grog-bone, and bone-tempered vessels in the assemblage from 41 TL7 (Table 1). About 74 percent of the sherds are from grog-tempered vessels, 13 percent are from grogbone-tempered vessels, and 13 percent are from bone-tempered vessels; a total of 26 percent of the sherds are from vessels that have had crushed and burned bone added to the paste as a temper.

Table 1. Ceramic assemblage from 41 TL7.

\begin{tabular}{lllll}
\hline Ware & Grog & Grog-Bone & Bone & N \\
\hline Plain & 143 & 16 & 19 & 178 \\
Fine & 1 & 2 & - & 3 \\
Utility & 46 & 15 & 14 & 75 \\
\hline Totals & 190 & 33 & 33 & 256 \\
\hline
\end{tabular}

Vessels with bone temper are particularly abundant in the fine ware (67 percent) and the utility ware (39 percent) sherds at the site. Conversely, more than 80 percent of the plain ware sherds are from vessels 


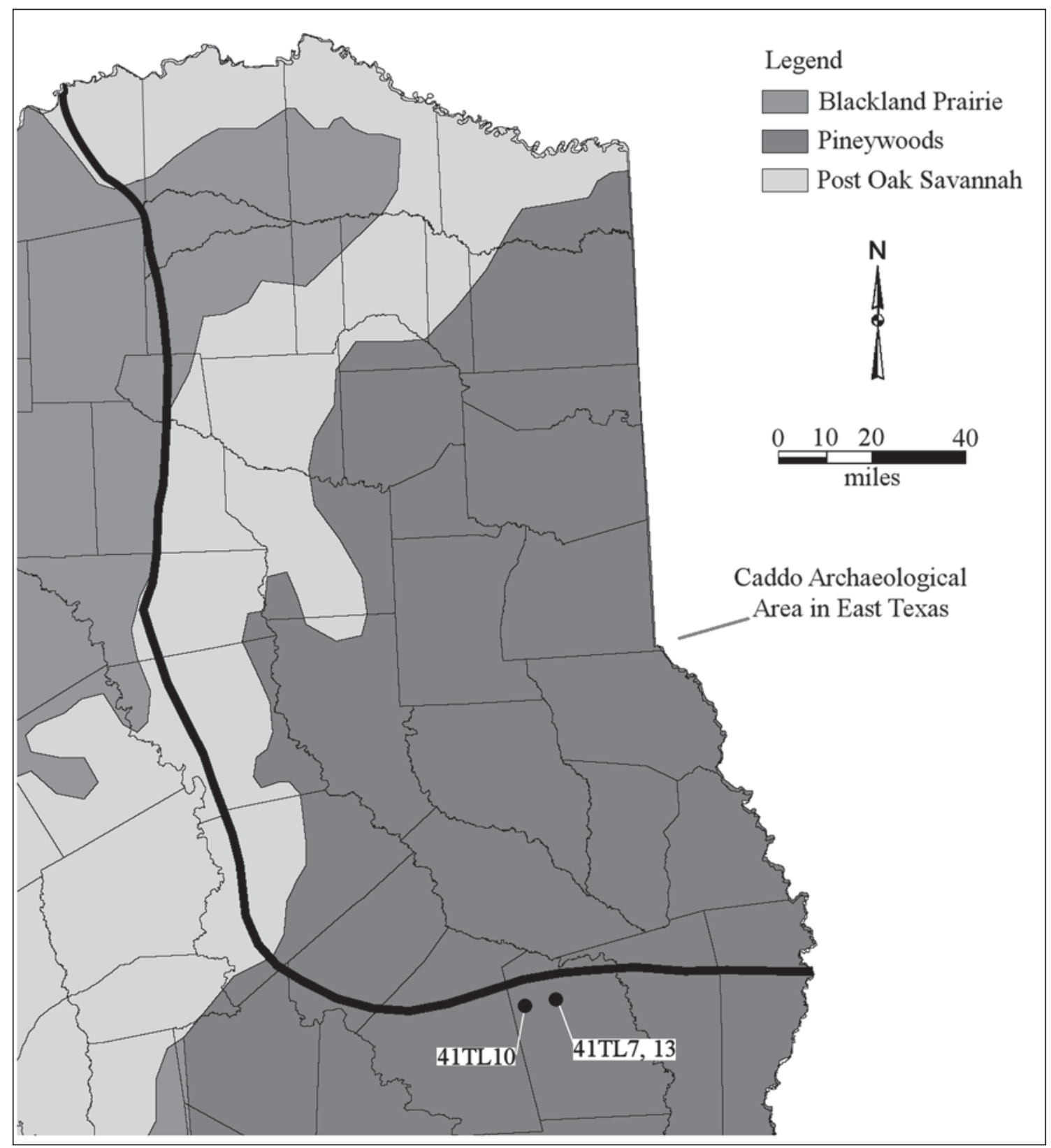

Figure 1. Location of 41TL7, Peachtree Village (41TL10), and Sturrock Place (41TL13) in Southeast Texas.

tempered only with grog (see Table 1), compared to 33 percent among the fine ware and 61 percent among the utility ware sherds.

The decorated sherds from 41TL7 ( $\mathrm{n}=78)$ include only a few fine wares (3.8 percent; sherds with engraved decorative elements) and a very high proportion of utility wares (96.2 percent; sherds with wet paste decorations) (Table 2). The first of the fine ware sherds is from a carinated bowl that has a series of fine-line diagonal engraved lines on the rim panel (Figure 2a); this is likely from an Early Caddo style (ca. A.D. 900-1200) Holly Fine Engraved vessel (see Suhm and Jelks 1962:77). The other two engraved sherds from the site appear to be from later Caddo vessels, most likely made and used after ca. A.D. 1400. One is a grog-bone-tempered carinated bowl sherd with a single horizontal engraved line above the carination and a set of closely-spaced curvilinear engraved lines on the rim panel itself (Figure 2b); this may be from a Late 
Caddo Poynor Engraved vessel (see Suhm and Jelks 1962:Plate 62). The third engraved sherd from 41 TL7 is likely also from a Poynor Engraved vessel (Figure 2c; see Suhm and Jelks 1962:Plate 62e). It has diagonal and diagonal opposed zones - probably forming part of a larger triangular element on the rim-filled with hatched engraved lines pitched in different directions.

Table 2. Decorative methods and elements in the fine ware and utility wares in the 41TL7 ceramic assemblage.

\begin{tabular}{llll}
\hline Decorative method and elements & Rim & Body & N
\end{tabular}

Fine ware

Engraved

fine line diagonal engraved lines*

diagonal and diagonal opposed zones filled with hatched lines

horizontal and set of curvilinear engraved lines*

\section{Utility ware}

\section{Brushed}

diagonal brushing marks

horizontal brushing marks

overlapping brushing marks

parallel brushing marks

$\begin{array}{lll}- & 1 & 1 \\ - & 1 & 1 \\ - & 1 & 1\end{array}$

\section{Brushed-Incised}

parallel brushed-incised marks and lines

\section{Brushed-Punctated}

parallel brushed marks with tool punctated rows

pushed through the brushing

\section{Incised}

curvilinear incised line, wide-line

diagonal incised line

opposed incised lines

parallel incised lines

straight incised line

\section{Incised-Punctated}

curvilinear incised line and adjacent tool punctated-

filled zone

curvilinear incised line and adjacent tool punctated-

filled zone and diagonal tool punctated row

straight incised line and adjacent circular punctated-

filled zone/rows

straight incised line and adjacent tool punctated- 
Table 2. Decorative methods and elements in the fine ware and utility wares in the 41TL7 ceramic assemblage, cont.

\begin{tabular}{llll}
\hline Decorative method and elements & Rim & Body & $\mathrm{N}$ \\
\hline $\begin{array}{l}\text { Pinched } \\
\text { parallel pinched ridges }\end{array}$ & - & 1 & 1 \\
$\begin{array}{l}\text { Pinched-Punctated } \\
\text { parallel pinched ridges adjacent to zone of tool } \\
\text { punctated rows }\end{array}$ & - & 1 & 1 \\
$\begin{array}{l}\text { Punctated } \\
\text { circular punctated row below the lip }\end{array}$ & & & \\
$\begin{array}{l}\text { circular punctated row } \\
\text { fingernail punctated rows } \\
\text { tool punctated row/rows }\end{array}$ & 1 & - & 1 \\
\hline Totals & /rows & - & 3 \\
\hline
\end{tabular}

*carinated bowl

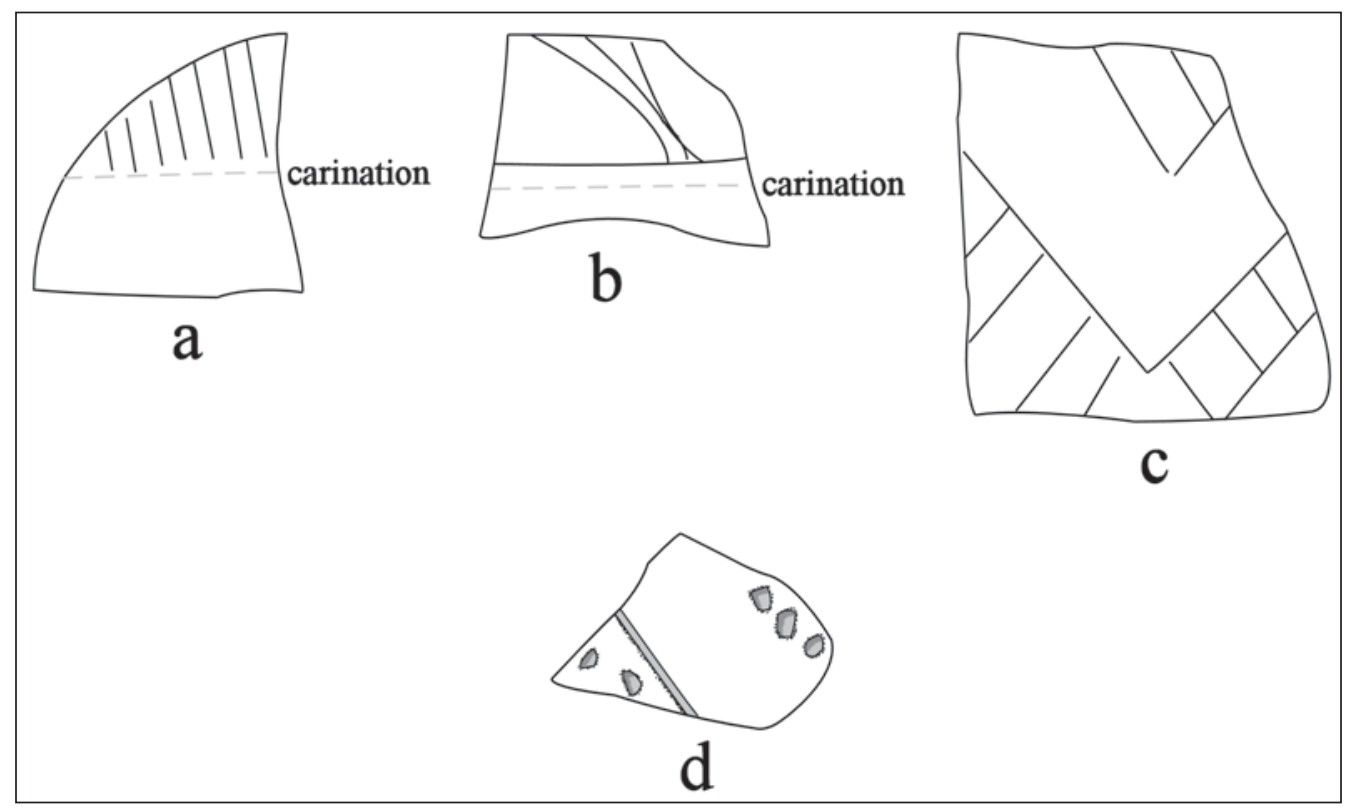

Figure 2. Selected decorated sherds from 41TL7: a-c. engraved; d, incised-punctated.

Approximately 33 percent of the decorated sherds from 41TL7, and 34.7 percent of the utility ware sherds, have brushing marks on vessel rim and body sherds; these are from Bullard Brushed jars. Another 4 percent have either brushed-incised or brushed-punctated decorative elements (see Table 2). This proportion of brushed sherds in the utility wares is consistent with a Late Caddo occupation in the Neches River basin. Other common utility wares in the assemblage are sherds with circular, fingernail or tool punctated decorative elements (29 percent of the utility wares); sherds with simple incised decorative elements (18.7 percent of the utility wares); and sherds with incised-punctated decorative elements (see Figure 2d; 10.7 percent of the utility wares). Two sherds (2.7 percent of the utility wares) are from Killough Pinched jars (see Suhm and Jelks 1962:7 with pinched or pinched-punctated decorative elements. 
There are also nine plain body sherds of Goose Creek Plain, var. unspecified in the assemblage. Goose Creek Plain is a Woodland period ceramic ware in this part of Southeast Texas, and indicates some use of the site before ca. A.D. 800 .

In addition to the ceramic vessel sherds in the 41TL7 artifact assemblage, there is one piece of burned clay and several lithic tools. These include three Perdiz arrow points (made of local petrified wood, red chert, and a red quartzite) and a fragment of a greenish-gray siliceous shale celt fragment.

\section{Peachtree Village (41TL10)}

Peachtree Village is reported to have been one of three 1830s Alibamu Indian villages on the Neches River in what is now Tyler County, Texas (Perttula 2010:150). The three villages had 103 families, 100 single men, and 64 unmarried women living in 69 wood or log houses; also among the villages were two large wood houses or temples.

The TARL assemblage from the Peachtree Village site includes 11 rim and body sherds. They are from vessels tempered with grog $(n=9)$, grog-bone $(n=1)$, and bone $(n=1)$. The one rim sherd has vertical brushing marks and five body sherds have either parallel brushing marks $(n=3)$ or parallel brushing marks and incised lines $(n=2)$. It is likely that these sherds are from $19^{\text {th }}$ century Chattahoochee Brushed jars made by Alibamu potters. This ware was made by both the Alibamu and Koasati in the $18^{\text {th }}$ and early $19^{\text {th }}$ centuries, first in Alabama and Georgia, and then in Louisiana and East Texas sites (Knight 1985; McCrocklin 1990; Perttula 2010).

\section{Sturrock Place (41TL13)}

The TARL sherd collection from the Sturrock Place includes 42 sherds from plain ware, fine ware, and utility ware vessels (Table 3 ). About 81 percent of the sherds are from grog-tempered vessels, another 14 percent are from grog-bone-tempered vessels, and 4.8 percent of the sherds are from vessels tempered with bone.

Table 3. Ceramic assemblage from the Sturrock Place (41TL13).

\begin{tabular}{lllll}
\hline Ware & Grog & Grog-Bone & Bone & N \\
\hline Plain ware & 14 & 4 & 1 & 19 \\
Fine ware & 1 & - & - & 1 \\
Utility ware & 19 & 2 & 1 & 22 \\
\hline Totals & 34 & 6 & 2 & 42 \\
\hline
\end{tabular}

Twenty-three sherds are from the decorated portions of vessels. Only 4 percent of the decorated sherds are from fine ware vessels, and the remainder are from utility ware vessels. The one fine ware vessel is a rim sherd with widely-spaced horizontal engraved lines (Table 4). 
Table 4. Decorative methods and elements in the fine ware and utility wares in the Sturrock Place (41TL13) ceramic assemblage.

\begin{tabular}{|c|c|c|c|}
\hline Decorative method and elements & Rim & Body & $\mathrm{N}$ \\
\hline \multicolumn{4}{|l|}{ Fine ware } \\
\hline \multicolumn{4}{|l|}{ Engraved } \\
\hline horizontal engraved lines, widely-spaced & 1 & - & 1 \\
\hline \multicolumn{4}{|l|}{ Utility ware } \\
\hline \multicolumn{4}{|l|}{ Brushed } \\
\hline parallel brushed marks & - & 2 & 2 \\
\hline \multicolumn{4}{|l|}{ Brushed-Incised } \\
\hline parallel brushed-incised marks and lines & - & 1 & 1 \\
\hline \multicolumn{4}{|l|}{ Incised } \\
\hline cross-hatched incised lines & 3 & - & 3 \\
\hline diagonal incised lines & 1 & - & 1 \\
\hline diagonal and cross-hatched incised lines & - & 1 & 1 \\
\hline horizontal incised lines & 1 & - & 1 \\
\hline horizontal incised lines, closely-spaced & 1 & - & 1 \\
\hline horizontal incised lines, widely-spaced & 1 & - & 1 \\
\hline parallel incised lines & - & 7 & 7 \\
\hline \multicolumn{4}{|l|}{ Incised-Punctated } \\
\hline $\begin{array}{l}\text { curvilinear incised line and adjacent zone of tool } \\
\text { punctates }\end{array}$ & - & 1 & 1 \\
\hline $\begin{array}{l}\text { horizontal and diagonal incised lines and triangular- } \\
\text { shaped zone filled with tool punctates }\end{array}$ & - & 1 & 1 \\
\hline \multicolumn{4}{|l|}{ Punctated } \\
\hline horizontal tool punctated row on folded over lip & 1 & - & 1 \\
\hline tool punctated rows & - & 1 & 1 \\
\hline Totals & 9 & 14 & 23 \\
\hline
\end{tabular}

Most of the utility ware sherds from the Sturrock Place have incised decorative elements (68 percent of the utility wares), including rims with cross-hatched incised lines (Figure 3b) as well as diagonal and horizontal incised lines. These may be from Davis Incised and Dunkin Incised vessels (see Suhm and Jelks 1962:Plates 18 and 19).

About 13.6 percent of the utility ware sherds have brushed or brushed-incised marks and lines (see Table 4). The relatively low proportion of brushed sherds in the ceramic assemblage — assuming the TARL collection is a representative sample - suggests the occupation at the Sturrock Place site likely took place between ca. A.D. $1200-1300$, in the early part of the Middle Caddo period.

Two utility ware sherds (9.1 percent) have incised-punctated elements (see Figure 3c-d). One of the sherds may be from a Maydelle Incised vessel with incised triangular zones filled with tool punctations (see Figure $3 \mathrm{c}$ ), while the other has a single curvilinear incised line next to a large zone of tool punctations (see Figure 3d). The last of the utility ware sherds from the Sturrock Place are a rim sherd with a horizontal row of tool punctations beneath the vessel lip and a body sherd with rows of tool punctations (see Table 4). 


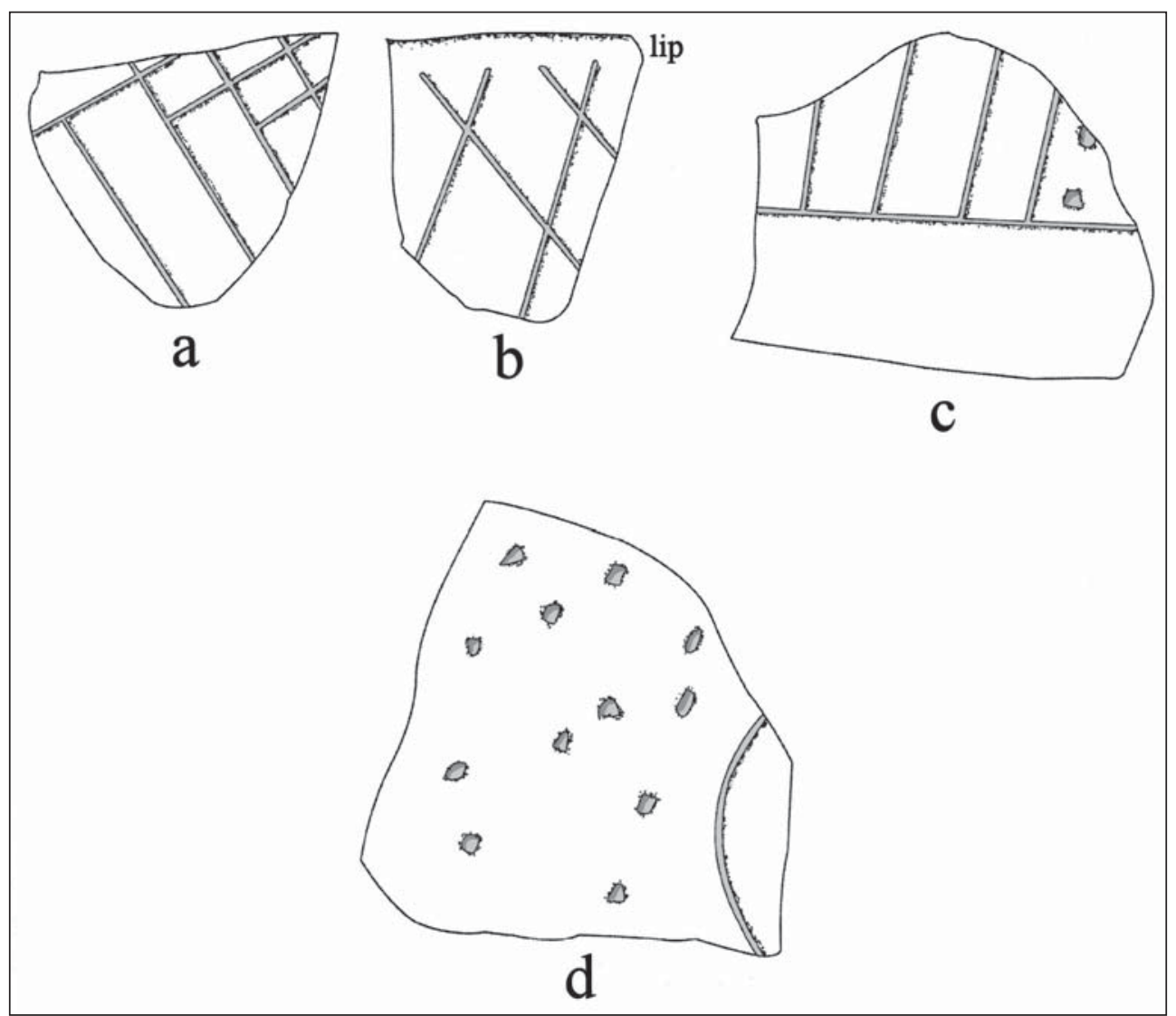

Figure 3. Selected decorated sherds from the Sturrock Place site (41TL13): a-b, incised; c-d, incised-punctated.

A whole ceramic vessel has been found at the Sturrock Place site, according to the TARL records. It is a Keno Trailed, var. Glendora bottle (see Schambach and Miller 1984:123 and Figure 11-18a-b) with a pedestal base (Figure 4). Schambach and Miller (1984:123) suggest this variety of Keno Trailed dates after A.D. 1680, and it has been found in Caddo sites on the Red River in southwestern Arkansas.

The bottle has interlocking trailed scrolls on the vessel body, placed between two upper and two lower horizontal trailed lines (see Figure 4). The bottle is ca. $14.0 \mathrm{~cm}$ in height, with a maximum body diameter of $12.7 \mathrm{~cm}$. The orifice diameter of the bottle neck is ca. $5.6 \mathrm{~cm}$, and the basal diameter is $5.1 \mathrm{~cm}$. Body wall thickness is ca. $4.8 \mathrm{~mm}$. There is no slip on the vessel's exterior surface, but this surface has been polished.

There also is a single plain body sherd and a base sherd from a Goose Creek Plain, var. unspecified vessel. The base sherd is from a conical-shaped vessel base.

\section{Summary and Conclusions}

The ceramic sherd assemblages from 41TL7, Peachtree Village (41TL10), and the Sturrock Place (41TL13) in the Neches River basin provide insights into the Native American use of these sites at different times over several hundred years, by Mossy Grove Woodland (cf. Story 1990), ancestral Caddo, and Alibamu peoples. The recovered ceramics from 41TL7 and the Sturrock Place indicate that the earliest use of these sites took place during the Woodland period (ca. 500 B.C. to A.D. 800), when Mossy Grove groups made and used sandy paste Goose Creek Plain, var. unspecified vessels. 


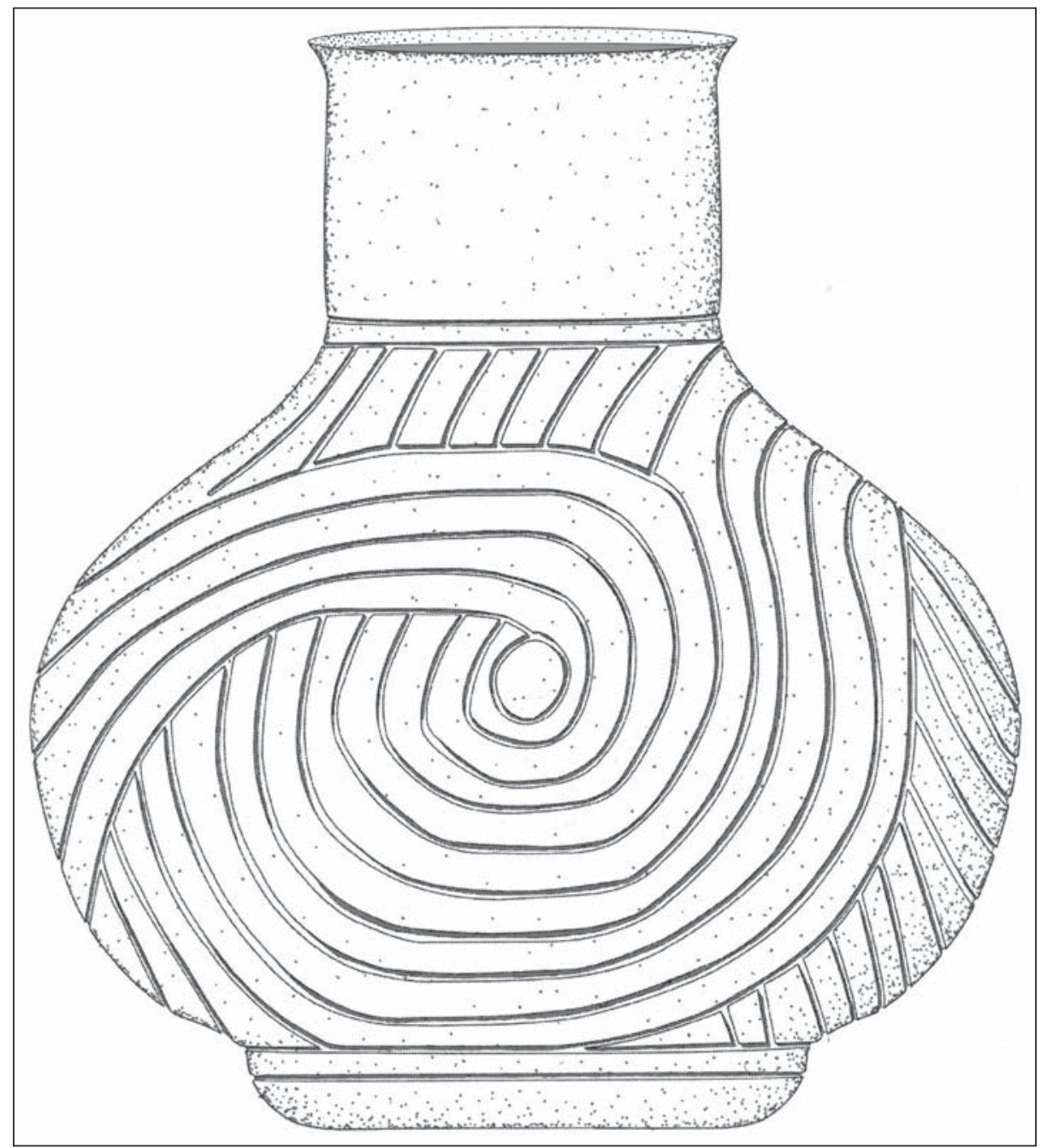

Figure 4. Keno Trailed, var. Glendora bottle reported from the Sturrock Place site (41TL13).

The principal aboriginal use of 41TL7 and the Sturrocks Place sites was by ancestral Caddo peoples that were affiliated with Caddo peoples living in both the Neches and Angelina River basins. The decorative methods and elements represented in the sherds from the two sites suggest there was a lightly-used Caddo settlement at 41TL7 that dated from ca. A.D. 900-1200, a settlement at the Sturrocks Place that dated from ca. A.D. 1200-1300, while the main Caddo settlement at 41TL7 was later, dating after ca. A.D. 1400; decorated sherds there resemble Poynor Engraved and Killough Pinched, ceramic types that occur in Late Caddo period contexts in the Neches-Angelina river basin. Lastly, the one whole ceramic vessel from the Sturrocks Place is a post-A.D. 1680 Keno Trailed, var. Glendora bottle. This bottle suggests that the site was used as a cemetery in Historic Caddo times.

Peachtree Village is one of three known 1830s Alibamu Indian villages on the Neches River. The small collection of sherds from the site are likely from $19^{\text {th }}$ century Chattahoochee Brushed jars made by Alibamu potters. This ware was made by both the Alibamu and Koasati in the $18^{\text {th }}$ and early $19^{\text {th }}$ centuries, first in Alabama and Georgia, and then in Louisiana and East Texas sites. 


\section{Acknowledgments}

Thanks to Marybeth Tomka at TARL for facilitating access to these Tyler County ceramic assemblages. Lance Trask prepared the figures in this article.

\section{References Cited}

Diggs Jr., G. M., B. L. Lipscomb, M. D. Reed and R. J. O’Kennon

2006 Illustrated Flora of East Texas, Volume One: Introduction, Pteridophytes, Gymnosperms, and Monocotyledons Sida, Botanical Miscellany, No. 26. Botanical Research Institute of Texas, Fort Worth.

Knight, V. J.

1985 Tukabatchee: Archaeological Investigations at an Historic Creek Town, Elmore County, Alabama, 1984. Report of Investigations No. 45. Office of Archaeological Research, Alabama State Museum of Natural History, University of Alabama, Tuscaloosa.

McCrocklin, C.

1990 The Red River Coushatta Indian Villages of Northwest Louisiana, 1790-1835. Louisiana Archaeology 12:129-178.

Perttula, T. K.

2010 Material Culture of the Koasati Indians of Texas. In The Archaeology of Native American-European Culture Contact, compiled by T. K. Perttula, pp. 147-159. Perspectives from Historical Archaeology, No. 3. Society for Historical Archaeology.

2012 The Archaeology of the Caddo in Southwest Arkansas, Northwest Louisiana, Eastern Oklahoma, and East Texas: An Introduction to the Volume. In The Archaeology of the Caddo, edited by T. K. Perttula and C. P. Walker, pp. 1-25. University of Nebraska Press, Lincoln.

Schambach, F. F. and J. E. Miller

1984 A Description and Analysis of the Ceramics. In Cedar Grove: An Interdisciplinary Investigation of a Late Caddo Farmstead in the Red River Valley, edited by N. L. Trubowitz, pp. 109-170. Research Series No. 23. Arkansas Archeological Survey, Fayetteville.

Story, D. A.

1990 Cultural History of the Native Americans. In The Archeology and Bioarcheology of the Gulf Coastal Plain, by D. A. Story, J. A Guy, B. A. Burnett, M. D. Freeman, J. C. Rose, D. G. Steele, B. W. Olive, and K. J. Reinhard, pp. 163-366. Research Series No. 38. 2 Vols. Arkansas Archeological Survey, Fayetteville. 